роботи майбутніх учителів початкової школи за новими оцінними стандартами і шкалами, зростання масовості вищої педагогічної освіти за рахунок певного зниження якості фахової підготовки. Розв'язання цих проблем - невідкладне завдання для майбутніх досліджень.

\title{
Література
}

1. Абдуллина О. А. Общепедагогическая подготовка учителя в системе высшего педагогического образования / О. А. Абдуллина. - Москва : Просвещение, 1990. - 141 с. 2. Гессен С. И. Основы педагогики. Введение в прикладную философию / Сергей Иосифович Гессен. - Москва : Школа-Пресс, 1995. - 448 с. 3. Гончаренко С. У. Український педагогічний словник/ Семен Устимович Гончаренко. - Київ : Либідь, 1997. - 376 с. 4. Дмитренко Т. А. Профессионально-ориентированные технологии обучения в системе высшего педагогического образования (на материале преподавания иностранных языков) : дисс. ... д-ра пед. наук : 13.00.08; 13.00 .02 / Дмитренко Татьяна Алексеевна. - Москва, 2004. 445 с. 5. Загвязинский В. И. Учитель как исследователь / Владимир Ильич Загвязинский. Москва : Педагогика, 1980. - 192 с. б. Ильин Е. П. Мотивация и мотивы / Евгений Павлович Ильин. - Санкт-Петербург : Питер, 2011. - 512 с. 7. Концептуальні засади розвитку педагогічної освіти України та ії інтеграції в європейський освітній простір (Затверджено наказом МОН України від 23.01.2004p. № 48) [Електронний ресурс]. - Режим доступу: http : // www.mon.gov.ua/ main.php?query=education 8. Педагогика: Большая современная энциклопедия / сост. Е. С. Рапацевич. - Минск : Современное слово, 2005. - 720 с. 9. Харламов И. Ф. Педагогика / Иван Федорович Харламов / под ред. П. И. Пидкасистого. Москва : Педагогическое общество России, 1998. - 638 с. 10. Ясперс К. Духовная ситуация времени [Электронный ресурс]/ Карл Ясперс.- Режим доступу: http://fast.filedownloads.org/?metod=FAST\&cost=FREE\& file_id $=2267675$

\section{ШЛЯХИ ОНОВЛЕННЯ ОБЧИСЛЮВАЛЬНОЇ ПРАКТИКИ У ПРОЦЕСІ ПІДГОТОВКИ БАКАЛАВРА МАТЕМАТИКИ}

Самойленко О. М. Шляхи оновлення обчислювальної практики у процесі підготовки бакалавра математики.

Статтю присвячено питанням професійної підготовки бакалаврів математики у процесі проведення навчальної обчислювальної практики. У статті описано особливості обчислювальної практики бакалаврів математичних дисциплін. Здійснено аналіз тематики проектів обчислювальної практики. Проаналізовано загальні закономірності структури та змісту програмних продуктів підтримки професійної діяльності учителів математики, які розробляють студенти під час обчислювальної практики.

Ключові слова: обчислювальна практика, математика, професійна підготовка, профільне навчання, навчальна практика.

Самойленко А. М. Пути усовершенствования вычислительной практики в процессе подготовки бакалавра математики.

Статья посвящена вопросам профессиональной подготовки бакалавров математики в процессе проведения учебной вычислительной практики. В статье описаны особенности вычислительной практики бакалавров математических дисциплин. Дан анализ тематики проектов вычислительной практики. Проанализированы общие закономерности структуры и 
содержания программных продуктов поддержки профессиональной деятельности учителей математики, которые разрабатывают студенты во время вычислительной практики.

Ключевые слова: вычислительная практика, математика, профессиональная подготовка, профильное обучение, учебная практика.

Samoylenko O. M. The ways of computing practice improving in teaching process of the Bachelor of Mathematics.

This article focuses on the issues of professional training of Bachelors of Mathematics in the process of educational computing practice. This article describes the features of computing practice of Bachelors of mathematical disciplines. The article reveals the analysis of computing practice projects. The article highlights the common patterns of structure and content software support of professional work of teachers of mathematics that students develop during computing practice.

Key words: computing practice, mathematics, professional training, specialized education, educational practice.

Якість сучасної освіти пов'язана 3 ефективністю використання сучасних засобів інформаційно-комунікаційних технологій. Професійна діяльність бакалавра математики неможлива без використання інформаційно-комунікаційних технологій, мережних ресурсів і професійних математичних пакетів. Ресурси, зокрема, електронні методичні матеріали, конспекти уроків, матеріали проектної діяльності тощо розробляються та постійно оновлюються. Програмні засоби підтримки професійної математичної діяльності, що орієнтовані на розв'язання математичних задач, належать до професійних математичних пакетів. Сучасні програмні продукти з математики недостатньо використовуються у процесі підготовки фахівців математичних спеціальностей, зокрема - під час проходження ними практики.

Навчальна обчислювальна практика $є$ важливою частиною системи професійної підготовки студентів, яка визначена державним освітнім стандартом математичних спеціальностей. Розвиток електронної обчислювальної техніки, створення алгоритмічних мов програмування високого рівня і широкого спектру математичного програмного забезпечення зумовили інтенсивне використання електронних обчислювальних машин у математичному моделюванні. Аналіз математичних моделей, як правило, вимагає знання основних алгоритмів обчислювальної математики і володіння методами їх програмної реалізації на електронних обчислювальних машинах. Поглибленню й закріпленню таких знань і навичок бакалаврів математики ефективно сприяє обчислювальна практика.

Провідні вітчизняні й зарубіжні науковці, зокрема, В. Дуванова, М. Жалдак, В. Лапінський досліджували значення практики у процесі навчання бакалавра математики. Питання методичної підготовки майбутніх учителів математики до професійної діяльності досліджували Л. Михайленко, М. Овчинникова, 3. Слєпкань. Методичні та теоретичні засади використання інформаційно-комунікаційних засобів вивчали В. Биков, О. Білоус, Ю. Богачков. Проте питання оновлення обчислювальної практики у процесі підготовки бакалавра математики потребує детального вивчення.

Обчислювальна практика є частиною професійної підготовки майбутніх бакалаврів математики. Зміст обчислювальної практики висуває вимоги до сучасної системи освіти і має бути оновленим, завдяки використанню нових інформаційних технологій. У зв'язку з цим виникає потреба детального вивчення шляхів оновлення обчислювальної практики студентів 
математичних спеціальностей.

Метою статmі є аналіз особливостей обчислювальної практики бакалаврів математичних дисциплін і тематики проектів обчислювальної практики; аналіз загальних закономірностей структури і змісту програмних продуктів підтримки професійної діяльності учителів математики, які розробляють студенти під час обчислювальної практики.

Застосування обчислювальної практики для підготовки бакалаврів математики актуально під час навчання учнів в умовах інформатизації системи освіти. Організація і проведення обчислювальної практики сприяє реалізації таких цілей:

- поглибленню й закріпленню здобутих за час навчання теоретичних і практичних знань із чисельних методів, методів оптимізації;

- набуттю студентами професійних навичок роботи 3 програмним забезпечення, орієнтованим на розв'язання задач обчислювальної математики;

- оволодінню сучасними інтегрованими програмними засобами для розв'язання математичних задач;

- удосконаленню навичок використання інформаційних технологій у навчальному процесі;

- розвитку логічного мислення студентів, підвищенню рівня їх математичної й обчислювальної культури.

Зміст обчислювальної практики висуває вимоги до рівня його засвоєння. Після завершення практики бакалавр математики повинен знати:

- основи побудови обчислювальних схем базових чисельних методів;

- основні етапи розроблення і відлагодження програми та методики її тестування;

- основні прийоми роботи 3 інструментальними програмними засобами, орієнтованими на розв'язання математичних задач;

- правила оформлення звіту з практики згідно зі встановленими вимогами.

Бакалавр математики після проходження обчислювальної практики повинен вміти:

- будувати математичну модель поставленої задачі і виконувати ії алгоритмізацію;

- реалізувати розроблений алгоритм у вигляді програми на мові високого рівня;

- використовувати наявні математичні програмні пакети для розв'язування поставленої задачі;

- використовувати сучасні засоби підготовки текстової документації.

Основними видами діяльності бакалавра математики під час навчальної обчислювальної практики є: пошук й опрацювання навчальної літератури; вивчення необхідних для розв'язування поставленої задачі програмних засобів; розроблення програмної реалізації задачі за допомогою вибраної мови програмування; розроблення тестових завдань для перевірки правильності роботи програм; підготовка звітної документації за результатами практики [2, с. 54; 6, с. 204].

У структурі підготовки бакалаврів математики передбачено два види навчальних практик [8, с. 93]. Навчальний план передбачає педагогічну й обчислювальну практики. Цей вид навчальної діяльності дозволяє студентам продемонструвати в реальних умовах навички професійної діяльності. Зупинимося детальніше на особливостях обчислювальної практики бакалаврів математики. У навчальному плані бакалаврів математики передбачено дві навчальні обчислювальні практики. Обидві ці обчислювальні практики пов'язані із застосуванням отриманих знань і умінь. Студенти під час практик розробляють програмні продукти, вміст яких відноситься до предметної галузі математики. Цей факт відображає 
специфіку отримання знань у суміжних галузях науки - інформатики та математики [5, c. 44].

Перша обчислювальна практика відбувається на третьому курсі. До обчислювальної практики бакалаври математики володіють усіма необхідними знаннями та вміннями для реалізації своїх професійних навичок. Завдання обчислювальної практики полягає у створенні середовища програмної оболонки, що включає методичні матеріали по одному 3 розділів шкільного курсу математики [6, с. 157]. Друга обчислювальна практика проводиться на четвертому курсі. Студенти розробляють засобами мови об'єктно-орієнтованого програмування програмну оболонку інформаційної системи підтримки роботи вчителя математики. Система містить базу даних організаційних матеріалів - таких, як: розклад уроків, список класу, предметні нормативні документи, методична скарбничка. Матеріали методичної скарбнички вбудовуються в інформаційну систему з програмної оболонки, створеної на попередній обчислювальній практиці, у розширеному і доопрацьованому вигляді.

На прикладі першої обчислювальної практики опишемо основні особливості структури і змісту навчальної діяльності студентів. На початку обчислювальної практики студентам повідомляються цілі і завдання їх роботи. Основною метою практики [3; 8, с. 101] $\epsilon$ формування загальнокультурних i професійних компетенцій студента - бакалавра математики, а саме: створення необхідної основи для використання сучасних засобів інструментальних систем у процесі вивчення студентами загальнопрофесійних і спеціальних дисциплін протягом усього періоду навчання i в майбутній професійній діяльності. Завданнями практики $є$ підготовка студентів до усвідомленого використання методів програмування під час розв'язання прикладних задач, а також використання із застосуванням технологій програмування можливостей освітнього середовища для забезпечення якості освіти [1, с. 29; 3]. Під час ознайомлювальної лекції студентам викладаються підходи до вибору тематики проекту, демонструються програмні продукти минулих років. На прикладі методичних програмних розробок обговорюються переваги і недоліки обраних методів програмної реалізації. Дискусія зі студентами спрямована на виявлення оптимальної методології програмної реалізації того чи того елемента розроблюваної системи [4; 7, с. 21$]$. Це дозволяє усвідомлено підійти до використання методів програмування під час розв'язання поставлених завдань обчислювальної практики. Після проведення інструктажу 3 техніки безпеки студенти розпочинають дослідницьку роботу. Вони обирають тематику проекту, визначають, чи буде проект індивідуальним або груповим, окреслюють його зміст. Потім проектують програмну оболонку, складають iï модель. На цьому етапі студенти будують UML-діаграми проекту.

Основний етап полягає в розробленні й наповненні навчально-методичним матеріалом програмної оболонки. Вибір теми з курсу шкільної математики варіюється у широких межах - від молодших до старших класів, від базового до поглибленого вивчення матеріалу. При цьому студентами приблизно в рівних частках висвітлюються питання алгебри й геометрії, зокрема - рішення лінійних рівнянь, рішення квадратних рівнянь, логарифм і його властивості тощо.

Проект у вигляді програмного продукту має обов'язкові елементи, серед яких можна виокремити:

- теоретичний і практичний матеріал для проведення уроків з теми;

- завдання для самостійної роботи учнів;

- контрольні завдання і матеріали для діагностики;

Педагогіка вищої та середної школи. - 2015. - Вип. 45 
- конспекти окремих уроків і позаурочних заходів;

- методичні рекомендації вчителю;

- історичні цікаві факти та довідкові матеріали;

- рекомендації по роботі з програмою.

Теоретичний матеріал реалізовано у вигляді компактних взаємопов’язаних блоків системи уроків. Він становить собою електронний мультимедійний варіант шкільного підручника. Практичні матеріали для проведення уроків містять приклади виконання завдань за темою рішення типових завдань. У цьому розділі наведені завдання для відпрацювання базових умінь і навичок досліджуваної теми. Залежно від складності вони можуть бути згруповані за рівнями засвоєння навчального матеріалу. Для всіх наведених завдань система містить відповіді, а для складних завдань рекомендації до розв'язання. Розділ «Самостійна робота» призначений для виконання учнями домашніх завдань. Він включає систему варіативних завдань для закріплення отриманих знань у позанавчальний час. Цей розділ як і розділи «Теорія» $\mathrm{i}$ «Практика» містить навчальний матеріал для різного рівня підготовки. До завдань розділу у завершальній частині наводяться відповіді. При проектуванні цих розділів студенти використовують як модулі інноваційні освітні автоматизовані системи побудови оптимальної траєкторії навчання, системи використовують математичні алгоритми, які дозволяють найбільш раціонально організувати спільну навчальну діяльність педагога і школярів. Розділ матеріалів для контролю та діагностування представлений у вигляді системи тестів. Бакалаври математики розробляють кілька варіантів тестів, що містять завдання в закритій формі з вибором варіантів відповідей і у відкритій формі. Завдання тесту паралельних форм тесту завантажуються у програму 3 текстових файлів. Під час використання автономної тестової оболонки у розробників з'являються додаткові можливості у вигляді готових інструментів для роботи 3 різноманітними тестовими формами.

Розділ «Конспекти уроків і заходів» містить оформлені в контексті парадигми особистісно зорієнтованого навчання дидактичні матеріали конспектів навчальних та позанавчальних занять. Конспекти - це зразок використання теоретичного матеріалу, практичних завдань і завдань для самостійної роботи програмної оболонки при підготовці до занять. Розділ «Методичні рекомендації» передбачає опис методології вивчення розглянутої тематики. Він описує низку питань методики підготовки до уроків, підходи до викладу матеріалу з теми, методичні способи і прийоми набуття практичних умінь і навичок виконання тематичних завдань. Розділ «Історія» включає коротку історичну довідку 3 досліджуваної теми - основні дати, прізвища науковців і їх внесок, цікаві факти і події. Розділ «Довідкові матеріали» містить формули і теореми. Також цей розділ передбачає покликання на літературні джерела, у яких можна знайти додаткові відомості з пропонованої тематики. У завершальному розділі містяться рекомендації щодо роботи 3 програмною оболонкою. У ньому описані вимоги до комп'ютера, особливості навігації в системі, конфігурація діалогових вікон, полів для введення даних і інших елементів, специфіка організації зворотного зв'язку з користувачем. Також у цьому розділі наведені відомості про авторів-розробників програми. Модулі програми реалізовані або у вигляді меню, або набором відповідних кнопок на формі проекту. За допомогою кнопок можна раціонально організувати навігаційну систему переходів при відкритті матеріалів усередині кожного розділу. Навчально-методичні матеріали програмної оболонки можна впровадити як у саму програму, так і відкривати у спеціалізованих для заданого виду файлових документів програмах. Наприклад, невеликі текстові документи можна завантажити у спеціальне поле, 
тоді як документи великого обсягу доцільно відкривати в текстовому редакторі. Презентації та відеоматеріали відкривають у відповідних програмних середовищах. Для контролю знань і вмінь за темою розробляють власні тестові оболонки, а не універсальні, що визначено широтою охоплення тематики дослідницького проекту.

Навчання студентів-бакалаврів основам проектування та розроблення програмних оболонок необхідне для професійної роботи в галузі математики. Під час створення такого роду програмних продуктів необхідні комплексні знання 3 візуального об'єктноорієнтованого програмування, яке нині упроваджується у процесвивчення шкільної програми з математики.

Отже, професійна підготовка бакалавра забезпечує отримання фундаментальних навичок побудови таких систем, що й відображено в задачах обчислювальної практики. Обчислювальна навчальна практика дозволяє супроводжувати процес навчання студентів математичних дисциплін та відкриває можливості автоматизувати окремі етапи процесу. Це не лише обов'язковий елемент освітнього процесу, але й важливий напрям оновлення всього процесу навчання. Модернізація обчислювальної практики майбутніх бакалаврів математики значно перерозподіляє навчальний час для поглибленого вивчення предмета одним із найбільш оптимальних способів. Застосування такої практики у процесі підготовки майбутніх бакалаврів математики розкриває широкі перспективи використання новітніх технологій у системі освіти.

\section{Література}

1. Дуванова В. С. Методический вестник. Материалы областного образовательного форума 2005 / В. С. Дуванова, 3. Н. Ковалевич, Г. С. Целта. - Брест, 2005. - 48 с. 2. Жалдак М. I. Комп’ютерно-орієнтовані засоби навчання математики, фізики, інформатики / М. І. Жалдак, В. В. Лапінський, М. І. Шут // Інформатика. - 2006. - №3 -4. С. 3-96. 3. Михайленко Л. Ф. До питання про методичну підготовку вчителя математики на заочному відділенні педвузу / Л. Ф. Михайленко, О.І.Матяш // Дидактика математики: проблеми і дослідження : [міжнародний збірник наукових робіт].- Вип. 16.- Донецьк, 2001. - С. 47-53. 4. Овчинникова М. В. Особистісний підхід як методологічна основа дослідження особистісно орієнтованої підготовки майбутніх вчителів математики до науково-дослідницької діяльності [Електронний ресурс] / М. В. Овчинникова // Проблеми сучасної педагогічної освіти. Педагогіка і психологія. - 2012. - Вип. 37(2). - С. 264-272. Режим доступу: http://nbuv.gov.ua/j-pdf/pspo_2012_37(2)_44.pdf 5. Основи стандартизації інформаційно-комунікаційних компетентностей в системі освіти України: [метод. рекомендації] / [В. Ю. Биков, О. В. Білоус, Ю. М. Богачков та ін.]; за заг. ред. В. Ю. Бикова, О. М. Спіріна, О. В. Овчарук. - Київ : Атіка, 2010. - 88 с. 6. Професійна підготовка вчителя математики у процесі навчання математичного аналізу / гол. ред. Г. О. Михалін. - Київ : НПУ імені М. П. Драгоманова, 2003. - 320 с. 7. Раков С. А. Формування математичних компетентностей учителя математики на основі дослідницького підходу в навчанні 3 використанням інформаційних технологій: автореф. дис. на здобуття наукового ступеня доктора пед. наук : спец. 3.00.02 «Теорія та методика навчання інформатики» / С. А. Раков. Харків : ХНПУ, 2005. - 44 с. 8. Слєпкань 3. І. Наукові засади педагогічного процесу у вищій школі / 3. І. Слєпкань. - Київ : НПУ імені М. П. Драгоманова, 2000. - 210 с. 